\title{
Yansıtıcı Düşünme Becerileri Eğitiminin Yabancı Dil Olarak Türkçe Öğreten Öğretmenlerin Ölçme ve Değerlendirme Sürecinin Gelişimine Etkisi*
}

\author{
Mete Yusuf Ustabulut ${ }^{* *}$, Mehmet Kara ${ }^{* * *}$ \\ Makale Geliş Tarihi: 26/12/2018 \\ Makale Kabul Tarihi: 04/01/2019 \\ DOI: $10.35675 /$ befdergi.503252
}

$\ddot{\boldsymbol{O}} z$

Bu araştırmanın temel amacı yabancı dil olarak Türkçe öğreten bir öğretmenin yansitıcı düşünmeyi ögretip yansitıcı düşünme becerilerini arttırmak ve bu yolla ölçme-değerlendirme sürecindeki gelişimine katkı sağlamaktır. Araştırmanın deseni, nitel araştırma desenlerinden aksiyon/eylem araştırmasıdır. Araştırmanın çalışma grubunu, İstanbul Aydın Üniversitesi’nden bir (1) öğreten oluşturmaktadır. Çalışma grubunun oluşturulmasında seçkisiz olmayan örnekleme yöntemlerinden amaçsal örneklem yöntemi kullanılmıştır. Amaçsal örnekleme yöntemlerinden ise ölçüt örneklem yaklaşımı tercih edilmiştir. Uygulama süreci sekiz haftadır. Araştırmada veri toplama araçlarl olarak, yansitıcı günlük (6 soru), özdeğerlendirme formu (1 soru), yarl-yapılandırılmış görüşme formu (7 soru), akran değerlendirme formu (6 soru), Veri analizinde ise nitel veri analiz tekniklerinden betimsel analiz ve içerik analizi kullanılmıştır. Araştırmada geçerlik ve güvenirliği uzman görüşleri ve kodlayıcılar arası uyum ile sağlanmıştır. Kodlayıcılar arası uyum, \%82 olarak saptanmıştır. Araştırmanın ortaya koyduğu bazı önemli sonuçlar ise şöyledir: Çalışma grubunda yer alan ögretmen sekiz hafta sonunda farkl düzeylerde yansitıcı düşünme becerilerini ve bu yolla mesleki gelişimlerine gelişstirmiş̧tir.

Anahtar Kelimeler: Ölçme ve değerlendirme, yabancılara Türkçe ögrretimi, yansıtıcı düşünme

\section{The Effect of Reflective Thinking Skills Training on Measurement and Assessment Processess of Turkish as a Foreign Language Teachers}

\begin{abstract}
The overall aim of this research is teaching reflective thinking skills to a teacher who teaches Turkish as a foreign language and to contribute development of measurement and evaluation skills of teacher. The study has a qualitative action research design. The study group consist of one (1) instructor from Istanbul Aydin University. The criterion sampling approach was preferred from the purposeful sampling methods. The implementation is eight weeks.

\footnotetext{
* Bu çalışma 1. yazar tarafindan 2. yazar danışmanlığında hazırlanan "Yansıtııı düşünme becerileri eğitiminin yabancı dil olarak Türkçe öğreten öğretmenler ve Türkçe öğretimi üzerindeki etkisi” başlıklı doktora tezinden üretilmiştir.

** Bayburt Üniversitesi, Eğitim Fakültesi, Türkçe ve Sosyal Bilimler Eğitimi Bölümü, Bayburt, Türkiye, meteustabulut@ bayburt.edu.tr, ORCID: 0000-0002-8864-645X

**** Gazi Üniversitesi, Eğitim Fakültesi, Türkçe Eğitimi Bölümü, Ankara, Türkiye, fmkr48@gmail.com, ORCID: 0000-0003-4691-5460
}

Kaynak Gösterme: Ustabulut, M.Y. ve Kara, M. (2019). Yansitıcı düşünme becerileri eğitiminin yabancı dil olarak türkçe öğreten öğretmenlerin ölçme ve değerlendirme sürecinin gelişimine etkisi. Bayburt Eğitim Fakültesi Dergisi, 14(27), 122-146. https://doi.org/10.35675/befdergi.503252 
Reflective diary (6 question), self-evaluation form (1question), semi-structured interview form (7 questions), peer evaluation form (6 question) were used as data collection tool. In the data analysis, descriptive analysis and content analysis were used. The validity and reliability of the study was provided by field-expert's opinions and inter-rater reliability. The inter-coder agreement was 0,82. Some important results of the research are as follows: The teacher in the study group developed reflective thinking skills at different levels after eight weeks.

Keywords: Measurement and assessment, teaching Turkish as a foreign language, reflective thinking

\section{Giriş}

Yabancı dil olarak Türkçe öğretiminde eğitim politikalarını yansıtan programlar ve programların dayandığı felsefe, aynı zamanda uygulama boyutunda amaç, içerik yöntem-teknik araç-gereç gibi durumlar üzerinde ciddiyetle çalışılması gereken konular olarak ele alınmaktadır. Bu noktada tüm bu süreçlerin uygulayıcısı olan öğretmenlerin niteliği gerçekleştirilen öğretimin niteliği üzerinde belirleyici rol oynamaktadır. Çünkü şüphesiz eğitim öğretim sürecinin en temel ve önemli öğelerinden birisi öğretmenlerdir. Eğitim öğretim sürecinde önemli bir role sahip olan öğretmenlerin niteliklerinin sorgulanması ve çağın gereklerine uygun olarak yetiştirilmesi bir zorunluluk olarak karşımıza çıkmaktadır.

Yabanc1 dil olarak Türkçe öğretimi alanı ve alan öğretmenliğine ilişkin Millî Eğitim Bakanlığınca 2010 yılında Marmaris'te ülke genelinde ilgili bölüm akademisyenleri ile ilgili kurum temsilcilerinin yer aldığı 'Yabancı Dil Olarak Türkçe Öğretimi ve Öğretmenliği Çalıştayı’ düzenlenmiştir. Çalıştayın sonucunda aşağıda yer alan maddeler rapor edilmiştir.

1. Mevcut lisans programları (Türk Dili ve Edebiyatı, Türkçe Eğitimi Bölümü vb.); yabancılara, yurtdışında yaşayan Türklere, Türk soylu ve akraba topluluklara Türkçenin öğretilmesi amacıyla kurulmamıştır.

2. Ülkemizde, Türkçenin yabancı dil olarak öğretimi alanında bağımsız bir lisans programı bulunmamaktadır.

3. Bu alanda üniversitelerimizdeki çok az sayıda olan lisansüstü programlar, içerik ve kapsam açısından birbirlerinden farklılık göstermektedir.

4. Yurtdışında Türkçe öğretmek amacıyla Bakanlıkça görevlendirilen öğretmenlere yönelik hizmet içi eğitim programları ihtiyaca cevap verememektedir.

5. Bu konuda hizmet veren kurumlar arasında işbirliği ve eşgüdüm bulunmamaktadır (Milli Eğitim Bakanlığı [MEB], 2010, s.152).

Türkçenin yabancı dil olarak öğretilmesi sürecinde, Türkçe öğretmenlerinin Türkçenin kendine özgü yapısal niteliklerini bilmesi anlamında alan bilgisine sahip olmasının oldukça önemli olduğu düşünülmektedir. Yabacı dil öğretmeni yetiştiren Eğitim Fakültesi programları mezunlarına göre Türkçe veya Türk dili ve edebiyatı 
eğitimi mezunlarının bu konuda daha yeterli bir durumda oldukları ifade edilebilir. Ancak aldıkları eğitim anadili Türkçe olan bireylere yönelik olması nedeniyle yabancılara Türkçe eğitimi bağlamında bazı eksiklikler söz konusu olmaktadır. Bu yüzden Yabancılara Türkçe öğretimi konusunda uzmanlaşmanın sağlanması amacıyla ayrı bölümler üzerinden öğretmen yetiştirmenin işlevsel olacağı düşünülmektedir.

Yansıtıcı düşünme ülkemizde eğitim programları ve uygulamaları açısından yeni tanıştı̆ııız, yeni bir kavram, bir bakış açısı olarak görülebilir. Özellikle 2006-2007 öğretim yılında yürürlüğe giren öğretmen yetiştirme programı problem çözen, öğrenmeyi öğreten, öğretmenler yetiştirmeyi hedeflemektedir (Yüksek Öğretim Kurulu, [YÖK], 2007). Bunun yanında öğretmen yetiştirme programı ile öğretmen adaylarına entelektüel bir donanım kazandırılması benimsenmiştir. Entelektüel donanımı desteklemek amacıyla gerçekleştirilen yansıtıcı uygulamalar bireye karşılaştığı problemlere çözüm üretmesi ve zorlukların üstesinden gelme becerisini kazandırmaktadır (Rodgers, 2002).

Toplumun ilerlemesi kendisini geliştirmesi okullarda verilecek olan kaliteli bir eğitime bağlıdır. $\mathrm{Bu}$ ise nitelikli öğretmenlerin varlığı gerçekleştirilebilecek bir hedeftir. Ancak öğretmen yetiştirme programlarında yansıtıcı düşünme becerisine vurgu yapılmasına karşın eğitim fakültelerinde bu beceriye yönelik derslerin yetersiz kalması, öğretmen yetiştirme sürecinde yansıtıcı düşünme uygulamalarını önemli hale getirmektedir (Dervent, 2012).

Öğretmenlerin ve öğretmen adaylarının yansıtıcı düşünme düzeyleri ve gelişimlerine yönelik araştırmaların ülkemizde yeni araştııılan bir alan olduğu ifade edilebilir. Çeşitli araştırmalarda (Alp ve Taşkın, 2007; Dolapçığlu, 2007; Yorulmaz, 2006) öğretmenlerin yansıtıcı düşünme kavramından tamamen habersiz olduklarına yönelik bulgulardan bahsedilmektedir. Yansıtıcı düşünme becerileri açısından ise öğretmenlerin ve öğretmen adaylarının yansıtıcı düşünme seviyesi olarak en düşük yansıtıcı düşünme düzeyi olan teknik yansıtma düzeyinde becerilere sahip oldukları vurgulanmaktadır (Yeşilbursa, 2011).

Yansıtıcı düşünme ile ilgili ülkemizde yapılan bilimsel çalışmalar incelendiğinde genellikle ilkokul öğretmenleri veya sınıf öğretmenleri bağlamında çalışıldığı görülmektedir (Alp ve Taşkın, 2007; Dolapçıŏglu, 2007) Yabancı dil olarak Türkçe öğretmen öğretmenlerin yansıtıcı düşünme becerilerine yönelik ise çalışmalar oldukça yetersiz kalmıştır. Gerçekleştirilen araştırma ile yabancı dil olarak Türkçe öğreten bir öğretmenin yansıtıcı düşünme becerileri ortaya çıkarılmaya çalışılacaktır. Çalışma bu yönü ile özgünlüğünü ortaya koymaktadır.

Bu çalışma, İstanbul Aydın Üniversitesine bağlı Türkçe Öğretim Merkezinde [TÖMER] A1 seviyesindeki dersler çerçevesinde gerçekleştirilecektir. Araştırma kapsamında bir öğretmene yansıtıcı düşünme becerileri kazandırılıp, bu becerileri geliştirmelerine yardımcı olunurken, yansıtıcı düşünmenin öğretmenin öğretim sürecinin değerlendirme aşamasındaki gelişiminin ortaya konulması amaçlanmıştır. 


\section{Yöntem}

$\mathrm{Bu}$ bölümde araştırmanın yöntemi, araştırmanın çalışma grubu, araştırmanın veri toplama araçları, araştırmada veri toplama süreci ve araştırmanın veri analiz süreci açıklanmıştır.

\section{Araştırmanın Yöntemi}

Yabancı dil olarak Türkçe öğreten bir öğretmene yansıtıcı düşünmeyi öğretip, mesleki gelişimlerine yardımcı olmak ve yansıtıcı düşünmenin öğretim sürecinin ölçmedeğerlendirme aşamasındaki gelişimini ortaya koymak amacıyla yapılan bu araştırma, incelenen durumun özelliğinden dolayı eylem araştırması biçiminde desenlenmiştir. Eylem araştırması, alanyazında çok farklı biçimlerde tanımlanmaktadır. Eylem araştırması, öğretim ortamında aynı zamanda araştırmacı olan öğretmenlerin, öğrencilerinin nasıl daha iyi öğrenebilecekleri, nasıl öğretim yaptıkları ve okullarının nasıl işlediği konusunda bilgi edinmek amacıyla yaptıkları sistemli bir araştırma sürecidir (Mills, 2003). Eylem araştırması bir problem durumuyla başlayan, veri toplamaya başlamadan önce iyi planlanması gereken, verilerin toplanması, analizi ve raporlaştırılmasında esneklik içeren ve düzenli gözlemler gerektiren bir süreçtir (Ay, 2010, Kuzu, 2005; Miller, 2007).

\section{Araştırmanın Çalış̧ma Grubu}

Nitel araştırmalarda örneklem elde etmede araştırmacı ilk olarak kimi ve neyi araştırma konusu edineceğine karar verir. Önerilen veya geliştirilmekte olan araştırmayla ilgi evren ve olaylar saptanır. Genellikle çalışma grubuna dâhil edilecek bireylerin sahip olması gereken ölçütler veya nitelikler belirlenir. Bu ölçütler araştırmaya kimlerin dâhil edileceğini, kimlerin dâhil edilmeyeceğini ayırt etmek için kullanılır. Zira bu ölçütler belirlendikten sonra artık çalışma grubunu elde etmek için harekete geçilir (Johnson ve Christensen, 2014, s.235).

$\mathrm{Bu}$ çalışmadaki ölçütler araştırmacı tarafindan geliştirilecektir. Bu çalışmadaki ölçüt öğretmenin TÖMER'de çalışıyor olması ve Türkçeyi yabancı dil olarak öğrenenlere A, kurunda ders veriyor olmasıdır. Bu bağlamda araştırmanın çalışma grubunu İstanbul Aydın Üniversitesi TÖMER'de yabancılara Türkçe öğreten bir öğretmen oluşturacaktır. Araştırmaya dâhil edilecek olan öğretmenin ismine yer verilmeyecek, öğretmenler Ö1 diye numaralandırılacaktır. Araştırmada diğer bir önemli ölçüt ise çalışma grubuna dâhil edilen öğretmenin araştırmaya katılmada gönüllü olmasıdır. Söz konusu öğretmen araştırmaya katkı sağlamak istemeleri, onların çalışma grubuna dâhil edilmesinde önemli bir ölçüt olmuştur. Özetle yukarıdaki kuramsal bilgilerden hareketle araştırmada kullanılan örneklem yöntemi, seçkisiz olmayan örnekleme yöntemlerinden amaçsal örneklemidir. Amaçsal örneklem yaklaşımlarından ise ölçüt örneklem yöntemi araştırmada kullanılmıştır. 


\section{Veri Toplama Araçları}

\section{Yansıtıcı günlük}

Yansıtıcı günlük sorularının altısı (6) ölçme ve değerlendirme alanından oluşmaktadır. Bahse konu ölçme aracı araştırmacı tarafından geliştirilmiştir.

1. Kullandığınız ölçme-değerlendirme yöntemlerinin etkililiği hususunda ne düşünüyorsunuz? Niçin?

2. Kullandığınız ölçme-değerlendirme yöntemlerinin etkili olmadığını düşünüyorsanız ne tür değişiklikler yapardınız? Niçin?

3. Kullandığınız ölçme/değerlendirme yöntemlerinin hedeflerinizle uygunluğu hususunda ne düşünüyorsunuz?

4. Ölçme/değerlendirme sürecinizin olumlu yönleri nelerdi?

5. Ölçme/değerlendirme sürecinizin olumsuz yönleri nelerdi?

6. Ölçme/değerlendirme sürecini yeniden yapılandıracak olsaydınız neler yapardınız?

\section{Öz değerlendirme formu}

Öz değerlendirme formu sorularının biri (1) ölçme ve değerlendirme alanından olmak üzere bir sorudan müteşekkildir. Öz değerlendirme formu araştırmacı tarafında ilgili literatüre dayalı olarak geliştirilmişstir.

1. Bugünkü dersimde nasıl bir ölçme-değerlendirme yapmayı tasarlamıştım? Ne yaptım? Neden yaptım? Kullandığım ölçme-değerlendirme yöntemleri etkili miydi? Nasıl yapsam daha etkili ve geçerli bir ölçme-değerlendirme yapmış olurdum?

\section{Yarı-yapılandırılmış görüşme formu}

Yarı-yapılandırılmış görüşme formu sorularının yedisi (7) ölçme ve değerlendirme alanından meydana gelmektedir. Görüşme formu ilgili literatürden hareketle araştırmacı tarafından geliştirilmiştir. Bahse konu veri toplama aracı araştırmacı tarafından geliştirmiştir.

1. Aldığınız eğitim ölçme-değerlendirme yaklaşımlarınızı nasıl etkiledi?

2. Aldığınız eğitim ölçme-değerlendirme hususunda size ne gibi katkılar sağladı? Neden?

3. Yaptığınız ölçme-değerlendirme etkinliklerinin uygunluğunu nasıl değerlendirişiniz? Amacınıza ulaşabildiniz mi?

4. Tuttuğunuz günlükler uygulama sürecinize nasıl bir etki yaptı? Neden? 
5. Yaptığınız öz değerlendirme etkinliklerinin size olan faydalarını nasıl değerlendirirsiniz?

6. Yaptığınız akran değerlendirme etkinliklerinin size nasıl fayda sağladığını düşünüyorsunuz?

7. Yaptığınız öğrenme denetimi etkinliklerinin size ne tür faydalar sağladığını düşünüyorsunuz?

\section{Akran değerlendirme formu}

Akran değerlendirme formu, altı (6) ölçme ve değerlendirme sorudan müteşekkildir. Sözü edilen form araştırmacı tarafından geliştirilmiştir.

1. İzlediğiniz kişinin ölçme-değerlendirme yöntemleri hakkında ne düşünüyorsunuz? Neden?

2. Seçilen ölçme-değerlendirme yöntemlerinin hedeflerle tutarlılığı hakkında ne düşünüyorsunuz?

3. Siz olsaydınız hangi ölçme-değerlendirme yöntemlerini kullanırdınız?

4. İzlediğiniz kişinin süreçte sergilediği yansıtıcı düşünme becerileri nelerdir?

5. Sizce kişi yansıtıcı düşünmeyi sınıf ortamında etkili kullanabildi mi?

6. Siz olsaydınız yansıtıcı düşünmeye yönelik ne tür etkinlikler yapardınız?

\section{Veri toplam araçlarının geçerliği ve güvenirliği}

Araştırma kullanılan veri toplama araçlarının geçerliğine dönük yansıtıcı düşünme alanında 2 uzman akademisyen görüşlerine başvurulmuştur. Veri toplama araçlarındaki soruların yansıtıcı düşünmeye ilişkin olduğu uzman görüşlerince de tasdik edilmiştir. Başka bir ifadeyle tüm sorular ölçmek istenilen kazanımları ölçmeye yöneliktir. Ölçme araçlarındaki soruların güvenirliğine ilişkin araştırma grubundan bağımsız olarak on öğretene söz konusu sorular yöneltilmiş ve soruların anlaşılırlığı doğrulanmıştır. Anlaşılmasında güçlük çekilen sorulara yönelik ise soru cümlelerinde iyileştirilmeye gidilmiştir.

\section{Verilerin Analizi}

Araştırmada ölçme araçlarından elde edilen verilerin analizinde öncelikle içerik analizi yöntemi işe koşulmuştur. Nitekim içerik analizi tarihçi ve edebiyatçıların doküman incelemesi için kullandığı bir uygulamadır (Merriam, 2013, s.144). Bu bağlamda söz konusu araştırma için dokümanlar ilgili ölçme araçlarındaki sorulara, öğretenlerin verdikleri cevaplardan oluşan içeriklerdir. İçerik analizinde okuyucunun kavrayabileceği şekilde türdeş veriler; belirlenen kavramlar ve temalar altında 
özetlenir. Bahse konu işlemin icrasında bazı süreçler uygulanmaktadır (Yıldırım ve Şimşek, 2013, s.259). İçerik analizinin temel süreçleri aşağıdaki gibidir:

i) "Problemi tanımlama: Araştırma sorusunu/amacını belirleme ve varsayımları formüle etme,

ii) Kategori sistemini oluşturma: Kategorileri tanımlama ve kodlama kurallarını belirleme,

iii) Ölçüm birimlerini belirleme: Kodlama ve analiz birimlerini tanımlama ve örneklem yöntemini belirleme" (Gökçe, 2006, s.51).

Söz konusu bilgilerden hareket edildiğinde içerik analizi, içeriklerin kodlanması problemiyle, diğer bir ifadeyle kategorilerin oluşturulması, belirli kodlama ya da kayıt birimlerini saptama ile başlayacaktır (Bilgin, 2014, s.12). Kodlama işleminde analiz kategorileri (Berelson'dan aktaran Bilgin, 2014, s.12). Kategorilerin oluşturulmasında farklı yöntemler vardır (Tavşancıl ve Aslan, 2001, s.72-77). Araştırmada oluşturulan kategorilerde Taggart ve Wilson'nın (2005) yaptığı çalışmadan istifade edilmiştir.

\section{Bulgular ve Yorum}

Bu bölümde çalışmaya ait bulgular yer almaktadır. Öğretmenin 1. haftada ölçme ve değerlendirme alanındaki yansıtıcı düşünme bulguları Tablo 1'de sunulmuştur.

Tablo 1.

Öğretmenin 1. Haftada Ölçme ve Değerlendirme Alanında Yansıtıcı Düşünme Bulgularl

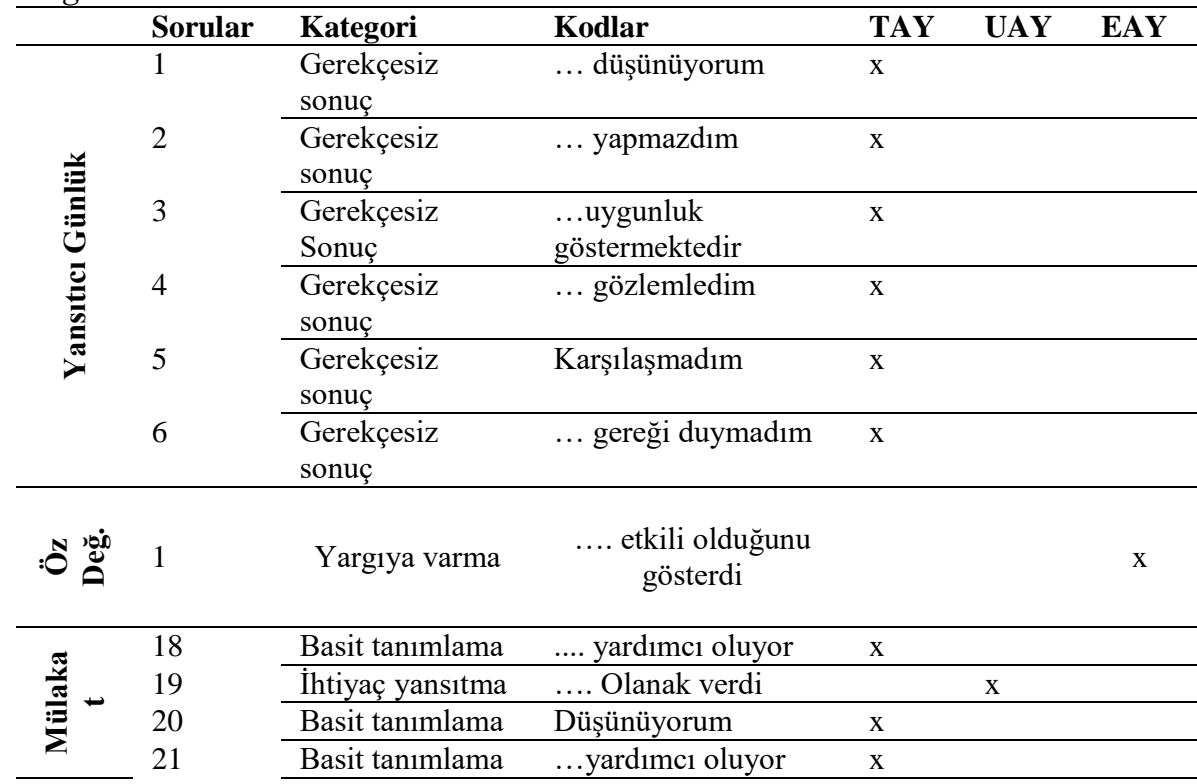




\begin{tabular}{|c|c|c|c|c|c|}
\hline & 22 & Yapılandırma & $\begin{array}{l}\text {... yapmamaya } \\
\text { çalışıyorum }\end{array}$ & & $\mathrm{x}$ \\
\hline & 23 & Basit tanımlama & ... düşünüyorum & $\mathrm{x}$ & \\
\hline & 24 & $\begin{array}{l}\text { Yeniden } \\
\text { yapılandırma }\end{array}$ & $\begin{array}{l}\ldots \text { anladım... } \\
\text { denetliyorum }\end{array}$ & & $\mathrm{x}$ \\
\hline \multirow{6}{*}{ 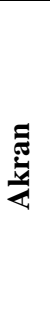 } & 11 & Basit tanımlama & $\ldots$ oluşturdu & $\mathrm{x}$ & \\
\hline & 12 & $\begin{array}{l}\text { Gerekçesiz } \\
\text { sonuç }\end{array}$ & .... Uygundu & $\mathrm{x}$ & \\
\hline & 13 & $\begin{array}{l}\text { Gerekçesiz } \\
\text { sonuç }\end{array}$ & .... Kullanırdım & $\mathrm{x}$ & \\
\hline & 14 & $\begin{array}{l}\text { Gerekçesiz } \\
\text { sonuç }\end{array}$ & ... getirmiştir & $\mathrm{x}$ & \\
\hline & 15 & Basit tanımlama & Evet & $\mathrm{x}$ & \\
\hline & 16 & Gerekçesiz öneri & ...sunardım & $\mathrm{x}$ & \\
\hline
\end{tabular}

Ö1 kodlu YDOTÖ öğretmenin yansitıcı günlüklerde yer alan ölçme ve değerlendirmeye yönelik sorulara vermiş olduğu cevaplar incelendiğinde öğretmenin soruların tamamına teknik düzeye yönelik ifadeler kullandığı görülmektedir. Ö1 kodlu öğretmenin ifadeleri incelendiğinde, teknik alanda gerekçesiz sonuca yönelik olduğu ortaya çıkmıştır. Bu duruma Ö1 kodlu öğretmenin ölçme değerlendirmeye yönelik sorulan soruya vermiş olduğu "Kullandĭ̆ım ölçme değerlendirme yöntemlerinin etkili olduğunu düşünüyorum..." şeklindeki ifadesi gerekçesiz sonuç kategorisine örnek olarak verilebilir.

Öz değerlendirme formunda ölçme ve değerlendirmeye yönelik sorulan soruda öğretmen eleştirel alanda yansitıcı ifadeler kullanmıştır. Bu ifade incelendiğinde öğretmenin içeriğe yönelik kullandığı "Öğrenciye geri bildirimleriyle yüzeysel bir ölçme değerlendirme yapmayı amaçladım. Geri dönütlerin olumlu yönde olması etkili olduğunu gösterdi...." şeklindeki ifade yargıya varmaya örnek teşkil etmektedir.

Ölçme ve değerlendirmeye yönelik sorulan mülakat sorularına öğretmen ağırlıklı olarak teknik alanda yansıtma alanına uygun ifadeler kullanmıştır. Aynı zamanda eleştirel alanda iki ve uygulama alanında yansıtmadan bir tane yansıtma yaptığ 1 görülmektedir. Öğretmenin teknik alandaki cevaplarına bakıldığında basit tanımlama kategorisinde kullandığı göze çarpmaktadır. Uygulama alanında ihtiyaç yansıtma, eleştirel alanda ise yapılandırma ve yeniden yapılandırma kategorilerinde yansıtma yaptığı görünmektedir. Öğretmenin "Problem olmadığını düşünüyorum..." şeklinde ifadeleri basit tanımlamaya vardığını göstermektedir.

Öğretmenin akran değerlendirmesindeki ifadeleri analiz edildiğinde soruların tamamına teknik düzeyde yansıtmalarda bulunduğu ortaya çımıştır. Teknik alandaki yansıtıcı ifadeler basit tanımlama ve gerekçesiz sonuç, gerekçesiz öneri şeklindedir. Gerekçesiz sonuç kategorisindeki yansıtmaya örnek olarak "Konusuyla ilgili sorumluluğu yerine getirmiştir..." şeklindeki yansıtma verilebilir.

Öğretmenin 2. haftada ölçme ve değerlendirme alanındaki yansıtıcı düşünme bulguları Tablo 2'de sunulmuştur. 
Tablo 2 .

Öğretmenin 2. Haftada Ölçme ve Değerlendirme Alanında Yansıtıcı Düşünme Bulgulart

\begin{tabular}{|c|c|c|c|c|c|c|}
\hline & Sorular & Kategori & Kodlar & TAY & UAY & EAY \\
\hline \multirow{6}{*}{ 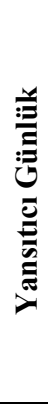 } & 1 & $\begin{array}{l}\text { Gerekçesiz } \\
\text { sonuç }\end{array}$ & ... ele aldim & $X$ & & \\
\hline & 2 & $\begin{array}{l}\text { Gerekçesiz } \\
\text { sonuç }\end{array}$ & ... düşünüyorum & $X$ & & \\
\hline & 3 & $\begin{array}{c}\text { Gerekçesiz } \\
\text { Sonuç }\end{array}$ & ...uygun buluyorum & $X$ & & \\
\hline & 4 & $\begin{array}{l}\text { Gerekçesiz } \\
\text { sonuç }\end{array}$ & $\ldots$ aldim & $X$ & & \\
\hline & 5 & $\begin{array}{c}\text { Nedensellik } \\
\text { Oluşturma }\end{array}$ & $\begin{array}{c}\text {..nedeniyle olumsuz } \\
\text { bir sonuçtur. }\end{array}$ & & $\mathrm{x}$ & \\
\hline & 6 & Öneri & ... geliştirirdim & & & $\mathrm{X}$ \\
\hline סُ & 1 & Yapılandırma & .... yapabilirdim & & & $\mathrm{X}$ \\
\hline \multirow{7}{*}{ 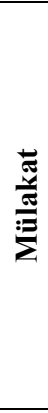 } & 18 & İhtiyaç yansıtma & .... yardimc1 oluyor & & $\mathrm{x}$ & \\
\hline & 19 & İhtiyaç yansıtma & .... Seçmemi sağladı & & $\mathrm{x}$ & \\
\hline & 20 & $\begin{array}{c}\text { Basit } \\
\text { Tanımlama }\end{array}$ & ..... düşünüyorum & $\mathrm{x}$ & & \\
\hline & 21 & Basit tanımlama & ...yardımc1 oluyor & $\mathrm{x}$ & & \\
\hline & 22 & Yapılandirma & $\begin{array}{c}\text {... yapmamaya } \\
\text { çallş̧1yorum }\end{array}$ & & & $\mathrm{x}$ \\
\hline & 23 & Basit tanımlama & $\begin{array}{l}\text {... fayda sağladığını } \\
\text { düşünüyorum }\end{array}$ & $\mathrm{x}$ & & \\
\hline & 24 & $\begin{array}{c}\text { Yeniden } \\
\text { yapılandirma }\end{array}$ & $\begin{array}{c}\text {... anliyorum... } \\
\text { düzeltiyorum }\end{array}$ & & & $\mathrm{x}$ \\
\hline \multirow{6}{*}{ 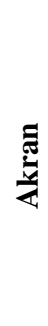 } & 11 & Basit tanımlama & ... paylaştı & $\mathrm{x}$ & & \\
\hline & 12 & $\begin{array}{l}\text { Gerekçesiz } \\
\text { sonuç }\end{array}$ & .... çıkmadı & $\mathrm{x}$ & & \\
\hline & 13 & $\begin{array}{c}\text { Gerekçesiz } \\
\text { sonuç }\end{array}$ & .... desteklerdim & $\mathrm{x}$ & & \\
\hline & 14 & Gerekçesiz öneri & $\begin{array}{l}\text {... materyal sunma } \\
\text { gibi }\end{array}$ & $\mathrm{x}$ & & \\
\hline & 15 & Basit tanımlama & Evet ...söyledi & $\mathrm{x}$ & & \\
\hline & 16 & Gerekçesiz öneri & Öz eleştiri yapardım & $\mathrm{X}$ & & \\
\hline
\end{tabular}

Ö1 kodlu YDOTÖ öğretmenin yansıtıcı günlüklerde yer alan ölçme ve değerlendirmeye yönelik sorulara vermiş olduğu cevaplar incelendiğinde öğretmenin dört adet teknik, eleştirel ve uygulama alanında ise bir adet yansıtma düzeyine yönelik ifadeler kullandığı görülmektedir. Ö1 kodlu öğretmenin ifadeleri incelendiğinde, teknik alanda gerekçesiz sonuç, uygulama alanında nedensellik oluşturma ve eleştirel alanda öneriye yönelik olduğu ortaya çıkmıştır. Bu duruma Ö1 kodlu öğretmenin ölçme değerlendirmeye yönelik sorulan soruya vermiş olduğu "Etkili olduğumu 
düşündüğüm için bir değişiklik yapmazdım...” şeklindeki ifadesi gerekçesiz sonuç kategorisine örnek olarak verilebilir.

Öz değerlendirme formunda ölçme ve değerlendirmeye yönelik sorulan soruda öğretmen eleştirel alanda yansıtıcı ifadeler kullanmıştır. $\mathrm{Bu}$ ifade incelendiğinde öğretmenin içeriğe yönelik kullandığı "Özellikle bir ölçme değerlendirme tasarlamadım. Süreç sonunda yapılanlarla, sorulan sorulara verilen cevaplarla bunu ölçme yoluna gittim. Bir sonraki günde yapacaklarıma yol gösterici olması adına bunu yaptım. Daha sistemli bir ölçme değerlendirme yapabilirdim...." şeklindeki ifade yapılandırmaya örnek teşkil etmektedir.

Ölçme ve değerlendirmeye yönelik sorulan mülakat sorularına öğretmen ağırlıklı olarak teknik alanda yansıtma alanına uygun ifadeler kullanmıştır. Aynı zamanda eleştirel ve uygulama alanında yansıtmadan iki tane yansıtma yaptığı görülmektedir. Öğretmenin teknik alandaki cevaplarına bakıldığında basit tanımlama kategorisinde kullandığı göze çarpmaktadır. Uygulama alanında ihtiyaç yansıtma, eleştirel alanda ise yapılandırma ve yeniden yapılandırma kategorilerinde yansıtma yaptı̆̆ görünmektedir. Öğretmenin “faydalarını alıyorum..." şeklinde ifadeleri basit tanımlamaya vardığını göstermektedir.

Öğretmenin akran değerlendirmesindeki ifadeleri analiz edildiğinde soruların tamamına teknik düzeyde yansıtmalarda bulunduğu ortaya çıkmıştır. Teknik alandaki yansıtıcı ifadeler basit tanımlama ve gerekçesiz sonuç, gerekçesiz öneri şeklindedir. Gerekçesiz sonuç kategorisindeki yansitmaya örnek olarak "Evet kullandl. Öğretmen ögrenci düşüncelerinin ortak olduğunu söyledi...” şeklindeki yansıtma verilebilir.

Öğretmenin 3. haftada ölçme ve değerlendirme alanındaki yansıtıcı düşünme bulguları Tablo 3 'te sunulmuştur.

Tablo 3.

Öğretmenin 3. Haftada Ölçme ve Değerlendirme Alanında Yansıtıcı Düşünme Bulgularl

\begin{tabular}{|c|c|c|c|c|c|c|}
\hline \multirow{7}{*}{ 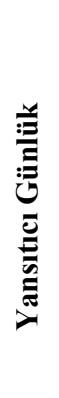 } & Sorular & Kategori & Kodlar & TAY & UAY & EAY \\
\hline & 1 & $\begin{array}{l}\text { Gerekçesiz } \\
\text { sonuç }\end{array}$ & ... düşünüyorum & $\mathrm{x}$ & & \\
\hline & 2 & $\begin{array}{l}\text { Gerekçesiz } \\
\text { sonuç }\end{array}$ & ... düşünüyorum & $\mathrm{x}$ & & \\
\hline & 3 & $\begin{array}{c}\text { Gerekçesiz } \\
\text { Sonuç } \\
\end{array}$ & ...düşünüyorum & $\mathrm{x}$ & & \\
\hline & 4 & Yargiya varma & ... gözlemledim & & & $\mathrm{x}$ \\
\hline & 5 & $\begin{array}{c}\text { Nedensellik } \\
\text { Oluşturma }\end{array}$ & $\begin{array}{l}\text { Nedeniyle zor } \\
\text { olmuştur. }\end{array}$ & & $\mathrm{x}$ & \\
\hline & 6 & Öneri & $\ldots$ isterdim & & & $\mathrm{x}$ \\
\hline
\end{tabular}




\begin{tabular}{|c|c|c|c|c|c|c|}
\hline 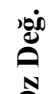 & 1 & Yapılandırma & .... Yetersizdi & & & $\mathrm{x}$ \\
\hline \multirow{7}{*}{ 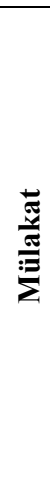 } & 18 & $\begin{array}{c}\text { Teori uygulama } \\
\text { bağlantıs1 }\end{array}$ & .... belirler oldum & & $\mathrm{x}$ & \\
\hline & 19 & İhtiyaç yansıtma & $\begin{array}{c}\ldots . \text { rahatlikla } \\
\text { belirliyorum }\end{array}$ & & $\mathrm{x}$ & \\
\hline & 20 & $\begin{array}{c}\text { Gerekçesiz } \\
\text { sonuç }\end{array}$ & ..... anliyorum & $\mathrm{x}$ & & \\
\hline & 21 & Basit tanımlama & ...göstermiştir & $\mathrm{x}$ & & \\
\hline & 22 & Yapılandirma & $\begin{array}{c}\ldots \text { daha iyisini } \\
\text { yapabilirim }\end{array}$ & & & $\mathrm{x}$ \\
\hline & 23 & $\begin{array}{c}\text { Nedensellik } \\
\text { ilkesi }\end{array}$ & $\begin{array}{c}\text {... böylece... teşvik } \\
\text { ediyor }\end{array}$ & & $\mathrm{x}$ & \\
\hline & 24 & Sorgulama & $\begin{array}{l}\text {... sağliyor... } \\
\text { denetliyorum. }\end{array}$ & & & $\mathrm{x}$ \\
\hline \multirow{6}{*}{$\frac{\Xi}{\pi}$} & 11 & Basit tanımlama & ... paylaşt1 & $\mathrm{x}$ & & \\
\hline & 12 & $\begin{array}{c}\text { Teori uygulama } \\
\text { bağlantıs1 }\end{array}$ & .... yapt1 & & $\mathrm{x}$ & \\
\hline & 13 & $\begin{array}{c}\text { Gerekçesiz } \\
\text { sonuç }\end{array}$ & .... yapardım & $\mathrm{x}$ & & \\
\hline & 14 & $\begin{array}{c}\text { Gerekçesiz } \\
\text { sonuç }\end{array}$ & $\ldots$ vard 1 & $\mathrm{x}$ & & \\
\hline & 15 & Basit tanımlama & Evet ...söyledi & $\mathrm{x}$ & & \\
\hline & 16 & $\begin{array}{l}\text { Gerekçesiz } \\
\text { öneri }\end{array}$ & .... yapard 1 & $\mathrm{x}$ & & \\
\hline
\end{tabular}

Ö1 kodlu YDOTÖ öğretmenin yansıtıcı günlüklerde yer alan ölçme ve değerlendirmeye yönelik sorulara vermiş olduğu cevaplar incelendiğinde öğretmenin üç adet teknik, eleştirel alanda iki tane ve uygulama alanında ise bir adet yansıtma düzeyine yönelik ifadeler kullandığı görülmektedir. Ö1 kodlu öğretmenin ifadeleri incelendiğinde, teknik alanda gerekçesiz sonuç, uygulama alanında nedensellik oluşturma ve eleştirel alanda öneriye yönelik olduğu ortaya çıkmıştır. Bu duruma Ö1 kodlu öğretmenin ölçme değerlendirmeye yönelik sorulan soruya vermiş olduğu "Kullandı̆̆ım ölçme ve değerlendirme yöntemlerinin uygun olamadı̆̆ını düşünmü̈yorum..." şeklindeki ifadesi gerekçesiz sonuç kategorisine örnek olarak verilebilir.

Öz değerlendirme formunda ölçme ve değerlendirmeye yönelik sorulan soruda öğretmen eleştirel alanda yansıtıcı ifadeler kullanmıştır. Bu ifade incelendiğginde öğretmenin içeriğe yönelik kullandı̆̆ "Her zamanki gibi soru-cevaplarla işleyen bir süreç ile ögrenci cevaplarından kuralı ögrenip ögrenmediklerini ölçmeye çalıştım. Ölçme değerlendirme etkili olmakla beraber yetersizdi. Fakat ögrencilerin ders bitiminde bu kuralın yer aldlğı cümlelere başvurması bir bakıma ölçme değerlendirme işlemidir...." şeklindeki ifade yapılandırmaya örnek teşkil etmektedir. 
Ölçme ve değerlendirmeye yönelik sorulan mülakat sorularına öğretmen ağırlıklı olarak uygulama ve teknik alanda yansıtma alanına uygun ifadeler kullanmıştır. Aynı zamanda eleştirel alanında yansıtmadan bir tane yansıtma yaptığ görülmektedir. Öğretmenin uygulama alandaki cevaplarına bakıldığında teori uygulama bağlantısı, ihtiyaç yansıtma ve nedensellik ilkesi kategorilerinde kullandığı göze çarpmaktadır. Teknik alanda ise gerekçesiz sonuç ve basit tanımlama kategorilerinde yansıtma yaptı̆̆ değerlendirmeyi rahatllkla belirleyebiliyorum. Sonuçlarını ona göre düzenliyorum..." şeklinde ifadeleri ihtiyaç yansıtma vardı̆̆ını göstermektedir.

Öğretmenin akran değerlendirmesindeki ifadeleri analiz edildiğinde soruların çoğunluğuna teknik düzeyde yansıtmalarda bulunduğu ortaya çıkmıştır. Teknik alandaki yansıtıcı ifadeler basit tanımlama ve gerekçesiz sonuç, gerekçesiz öneri şeklindedir. Bunun yanı sıra uygulama alanında da yansıtma ifadelerde ortaya çımıştır. Gerekçesiz sonuç kategorisindeki yansıtmaya örnek olarak "evet kullandl. Öğretmen öğrenci düşüncelerinin ortak olduğunu söyledi...." şeklindeki yansıtma verilebilir.

Öğretmenin 4. haftada ölçme ve değerlendirme alanındaki yansıtıcı düşünme bulguları Tablo 4'te sunulmuştur.

Tablo 4.

Öğretmenin 4. Haftada Ölçme ve Değerlendirme Alanında Yansitıcı Düşünme Bulgularl

\begin{tabular}{|c|c|c|c|c|c|c|}
\hline & Sorular & Kategori & Kodlar & TAY & UAY & EAY \\
\hline \multirow{6}{*}{ 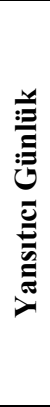 } & 1 & Yargiya Varma & $\begin{array}{c}\text {... anladıklarını ortaya } \\
\text { koymuştur. }\end{array}$ & & & $\mathrm{x}$ \\
\hline & 2 & $\begin{array}{c}\text { Nedensellik } \\
\text { oluşturma }\end{array}$ & ... yapardım. & & $\mathrm{x}$ & \\
\hline & 3 & $\begin{array}{l}\text { Gerekçesiz } \\
\text { Sonuç }\end{array}$ & ...düşünüyorum & $\mathrm{x}$ & & \\
\hline & 4 & $\begin{array}{l}\text { Gerekçesiz } \\
\text { Sonuç }\end{array}$ & $\ldots$ anlamışlardır & $\mathrm{x}$ & & \\
\hline & 5 & $\begin{array}{l}\text { Nedensellik } \\
\text { Oluşturma }\end{array}$ & $\begin{array}{l}\text { Nedeniyle iyi } \\
\text { gelmemiştir. }\end{array}$ & & $\mathrm{x}$ & \\
\hline & 6 & Öneri & $\ldots$ isterdim & & & $\mathrm{x}$ \\
\hline Oَّ & 1 & $\begin{array}{l}\text { İhtiyaç } \\
\text { Yansitma }\end{array}$ & $\begin{array}{c}\text {... Tasarlama } \\
\text { yapmadım }\end{array}$ & & $\mathrm{x}$ & \\
\hline \multirow{4}{*}{ 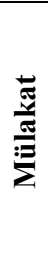 } & 18 & Yapılandırma & $\begin{array}{c}\text {.... istiyorum/ } \\
\text { çalışıyorum }\end{array}$ & & & $\mathrm{x}$ \\
\hline & 19 & $\begin{array}{c}\text { İhtiyaç } \\
\text { yansitma }\end{array}$ & $\begin{array}{l}\text {.... nasıl ölçeceğimi } \\
\text { kazandırdı. }\end{array}$ & & $\mathrm{x}$ & \\
\hline & 20 & Yargıya varma & $\begin{array}{l}\text {....-madığını } \\
\text { düşünüyorum }\end{array}$ & & & $\mathrm{x}$ \\
\hline & 21 & Basit tanımlama & Faydal1. & $\mathrm{x}$ & & \\
\hline
\end{tabular}




\begin{tabular}{|c|c|c|c|c|c|c|}
\hline \multirow{9}{*}{$\frac{\tilde{W}}{4}$} & 22 & Basit tanımlama & Faydalarını alıyorum. & $\mathrm{x}$ & & \\
\hline & 23 & $\begin{array}{c}\text { Gerekçesiz } \\
\text { sonuç }\end{array}$ & $\begin{array}{c}\begin{array}{c}\text {... olumlu dönütler } \\
\text { sağliyor. }\end{array} \\
\end{array}$ & $\mathrm{x}$ & & \\
\hline & 24 & Sorgulama & $\begin{array}{c}\ldots \text { hataları anlıyorum... } \\
\text { düzeltiyorum. }\end{array}$ & & & $\mathrm{x}$ \\
\hline & 11 & Basit tanımlama & $\begin{array}{c}\ldots \text { kulland } 1 . . . \\
\text { başarılıyd. }\end{array}$ & $\mathrm{x}$ & & \\
\hline & 12 & $\begin{array}{c}\text { Teori uygulama } \\
\text { bağlantıs }\end{array}$ & $\begin{array}{l}\text {.... konunun dişına } \\
\text { çımadi. }\end{array}$ & & $\mathrm{x}$ & \\
\hline & 13 & $\begin{array}{c}\text { Gerekçesiz } \\
\text { sonuç }\end{array}$ & .... kullanırdım. & $\mathrm{x}$ & & \\
\hline & 14 & Yargiya varma & $\begin{array}{l}\text {.. bağlantılı bir } \\
\text { etkinlikti. }\end{array}$ & & & $\mathrm{x}$ \\
\hline & 15 & Basit tanımlama & Evet etkili kullandi. & $\mathrm{x}$ & & \\
\hline & 16 & $\begin{array}{c}\text { İhtiyaç } \\
\text { yansitma }\end{array}$ & .... İsterdim/yapardım & & $\mathrm{x}$ & \\
\hline
\end{tabular}

Ö1 kodlu YDOTÖ öğretmenin yansıtıcı günlüklerde yer alan ölçme ve değerlendirmeye yönelik sorulara vermiş olduğu cevaplar incelendiğinde öğretmenin iki adet eleştirel, teknik alanda iki tane ve uygulama alanında ise iki adet yansıtma düzeyine yönelik ifadeler kullandığı görülmektedir. Ö1 kodlu öğretmenin ifadeleri incelendiğinde, teknik alanda gerekçesiz sonuç, uygulama alanında nedensellik oluşturma ve eleştirel alanda yargıya varma ve öneriye yönelik olduğu ortaya çıkmıştır. Bu duruma Ö1 kodlu öğretmenin ölçme değerlendirmeye yönelik sorulan soruya vermiş olduğu "Öğrencilere ölçme-değerlendirme yöntemi olarak kısa cevapl yazll yoklama ve boşluk doldurma uygulanmıştır. Uygulanan bu yöntemlerden elde edilen sonuçlar, ögrencilerin belirtme hal ekini anladıklarını ortaya koymuştur..." şeklindeki ifadesi yargıya varma kategorisine örnek olarak verilebilir.

Öz değerlendirme formunda ölçme ve değerlendirmeye yönelik sorulan soruda öğretmen uygulama alanda yansıtıcı ifadeler kullanmıştır. Bu ifade incelendiğinde öğretmenin içeriğe yönelik kullandığı "Özellikle tasarlama yapmadım. Süreç içerisinde gözlemlerle bu ölçümü yapıyorum. Ünite sonu etkinliklerin varllğı da bu ünite sonunda bizlere değerlendirme yaptırmaktadır..." şeklindeki ifade ihtiyaç yansıtmaya örnek teşkil etmektedir.

Ölçme ve değerlendirmeye yönelik sorulan mülakat sorularına öğretmen ağılıklı olarak eleştirel alanda ve teknik alanda yansıtma alanına uygun ifadeler kullanmıştır. Aynı zamanda uygulama alanında yansıtmadan bir tane yansıtma yaptığı görülmektedir. Öğretmenin eleştirel alandaki cevaplarına bakıldığında yargıya varma, sorulama ve yapılandırma kategorilerinde kullandığı göze çarpmaktadır. Teknik alanda ise gerekçesiz sonuç ve basit tanımlama kategorilerinde yansıtma yaptı̆̆ görünmektedir. Öğretmenin "Öğrencilerin genelinin başarılı olup olmadığını gösteriyor. Öğrencilerin eksikliklerini gösteriyor ve ek etkinlikler uygulamalar yapmamı sağllyor. Yaptığım hataları bir daha yapmamam gerektiğini anllyorum ve kendimi düzeltiyorum..." şeklinde ifadeleri sorulamaya vardığını göstermektedir. 
Öğretmenin akran değerlendirmesindeki ifadeleri analiz edildiğinde soruların çoğunluğuna teknik düzeyde yansıtmalarda bulunduğu ortaya çıkmıştır. Teknik alandaki yansitıcı ifadeler basit tanımlama ve gerekçesiz sonuç şeklindedir. Bunun yanı sıra uygulama alanında ve eleştirel alanda da yansıtma ifadelerde ortaya çıkmıştır. Gerekçesiz sonuç kategorisindeki yansıtmaya örnek olarak "Evet etkili kullanabildi...." şeklindeki yansıtma verilebilir.

Öğretmenin 5. haftada ölçme ve değerlendirme alanındaki yansıtıcı düşünme bulguları Tablo 5'te sunulmuştur.

Tablo 5.

Öğretmenin 5. Haftada Ölçme ve Değerlendirme Alanında Yansitıcı Düşünme Bulgulart

\begin{tabular}{|c|c|c|c|c|c|c|}
\hline & $\begin{array}{c}\text { Sorula } \\
\mathbf{r}\end{array}$ & Kategori & Kodlar & $\begin{array}{c}\text { TA } \\
\text { Y }\end{array}$ & $\begin{array}{c}\text { UA } \\
\mathbf{Y}\end{array}$ & $\begin{array}{c}\text { EA } \\
\mathbf{Y}\end{array}$ \\
\hline \multirow{6}{*}{$\begin{array}{c}\text { Yansitıc } \\
1 \\
\text { Günlük }\end{array}$} & 1 & $\begin{array}{c}\text { Yapılandırm } \\
\text { a } \\
\end{array}$ & $\begin{array}{c}\text { Gözden geçirdim, } \\
\text { bunlard } 1\end{array}$ & & & $\mathrm{x}$ \\
\hline & 2 & Öneri & $\begin{array}{c}\text { nedeniyle } \ldots \\
\text { yapabilirdi. }\end{array}$ & & & $\mathrm{x}$ \\
\hline & 3 & Öneri & $\begin{array}{c}\text { nedeniyle } \ldots \\
\text { yapabilirdi. }\end{array}$ & & & $\mathrm{x}$ \\
\hline & 4 & $\begin{array}{l}\text { Uygulamada } \\
\text { Yansitma }\end{array}$ & $\begin{array}{l}\text { Öğrenciler } \\
\text { yapabilirdi }\end{array}$ & & $\mathrm{x}$ & \\
\hline & 5 & $\begin{array}{l}\text { Uygulamada } \\
\text { Yansitma }\end{array}$ & $\begin{array}{l}\text { Öğrenciler } \\
\text { yapabilirdi }\end{array}$ & & $\mathrm{x}$ & \\
\hline & 6 & Öneri & $\begin{array}{c}\text {...nedeniyle o } \\
\text { bunu yapabilirdi. }\end{array}$ & & & $\mathrm{x}$ \\
\hline \multirow[t]{4}{*}{ Öz Dĕ̆. } & 1 & $\begin{array}{c}\text { Yargiya } \\
\text { Varma }\end{array}$ & $\begin{array}{c}\ldots \text {.etkili } \\
\text { yapabildim }\end{array}$ & & & $\mathrm{x}$ \\
\hline & 18 & $\begin{array}{l}\text { Uygulamada } \\
\text { Yansitma }\end{array}$ & $\begin{array}{c}\text { Uygulamalar } \\
\text { yardımc oluyor }\end{array}$ & & $\mathrm{x}$ & \\
\hline & 19 & $\begin{array}{l}\text { Yargiya } \\
\text { Varma }\end{array}$ & $\begin{array}{c}\text {...bana katk1 } \\
\text { sağladı }\end{array}$ & & & $\mathrm{x}$ \\
\hline & 20 & $\begin{array}{l}\text { Uygulamada } \\
\text { Yansitma }\end{array}$ & $\begin{array}{c}\text { Uygulamayı } \\
\text { değerlendiriyorum } \\
\text {, düşünüyorum }\end{array}$ & & $\mathrm{x}$ & \\
\hline \multirow[t]{4}{*}{ Mülakat } & 21 & $\begin{array}{c}\text { Yargiya } \\
\text { Varma }\end{array}$ & $\begin{array}{l}\text {...bana katk1 } \\
\text { sağladı }\end{array}$ & & & $\mathrm{x}$ \\
\hline & 22 & $\begin{array}{l}\text { Yargiya } \\
\text { Varma }\end{array}$ & $\begin{array}{c}\text {...cevaplar } \\
\text { sağlayabiliyorum }\end{array}$ & & & $\mathrm{x}$ \\
\hline & 23 & $\begin{array}{l}\text { Yargiya } \\
\text { Varma }\end{array}$ & $\begin{array}{l}\text { Fayda sağladığını } \\
\text { düşünüyorum }\end{array}$ & & & $\mathrm{x}$ \\
\hline & 24 & $\begin{array}{l}\text { Yargiya } \\
\text { Varma }\end{array}$ & ....iyi oluyor & & & $\mathrm{x}$ \\
\hline
\end{tabular}




\begin{tabular}{|c|c|c|c|c|c|}
\hline \multirow{6}{*}{ Akran } & 11 & $\begin{array}{l}\text { Yargiya } \\
\text { Varma }\end{array}$ & O...yapabilmiştir & & $\mathrm{X}$ \\
\hline & 12 & $\begin{array}{l}\text { Yargiya } \\
\text { Varma }\end{array}$ & O...yapabilmiştir & & $\mathrm{x}$ \\
\hline & 13 & $\begin{array}{c}\text { Gerekçesiz } \\
\text { Öneri }\end{array}$ & O bunları yapabilir & $\mathrm{x}$ & \\
\hline & 14 & $\begin{array}{l}\text { Yargiya } \\
\text { Varma }\end{array}$ & O yapamad 1 , yapt 1 & & $\mathrm{X}$ \\
\hline & 15 & $\begin{array}{c}\text { Gerekçesiz } \\
\text { Sonuç }\end{array}$ & Kismen & $\mathrm{x}$ & \\
\hline & 16 & Öneri & O yapabilirdi & & X \\
\hline
\end{tabular}

Ö1 kodlu YDOTÖ öğretmenin yansıtıcı günlüklerde yer alan ölçme ve değerlendirmeye yönelik sorulara vermiş olduğu cevaplar incelendiğinde öğretmenin dört adet eleştirel, uygulama alanında ise iki adet yansıtma düzeyine yönelik ifadeler kullandığ1 görülmektedir. Ö1 kodlu öğretmenin ifadeleri incelendiğinde, eleştirel alanda yapılandırma ve öneriye yönelik olduğu ortaya çıkmıştır. Bu duruma Ö1 kodlu öğretmenin ölçme değerlendirmeye yönelik sorulan soruya vermiş olduğu "Çoktan seçmeli ve doğru yanlış sorularıyla hazırladı̆̆ım fotokopiyi öğrencilere dağıttım. Konunun anlatılmasının ardından öğrenciler soruları çözdüler. Kullandığım ölçme değerlendirme yöntemlerinin etkili olduğunu düşünüyorum ancak geliştirilebilir..." şeklindeki ifadesi yapılandırma kategorisine örnek olarak verilebilir.

Öz değerlendirme formunda ölçme ve değerlendirmeye yönelik sorulan soruda öğretmen eleştirel alanda yansitıcı ifadeler kullanmıştır. Bu ifade incelendiğinde öğretmenin içeriğe yönelik kullandığı "Ders esnasında ve sonunda birlikte yanıtlanan alıştırmalarla ve sorulara verilen cevaplarla bir değerlendirme yapmayı tasarlamıştım. O dersteki hedeflerime yönelik etkiliydi...." şeklindeki ifade yargıya varmaya örnek teşkil etmektedir.

Ölçme ve değerlendirmeye yönelik sorulan mülakat sorularına öğretmen ağırlıklı olarak eleştirel alanda yansıtma alanına uygun ifadeler kullanmıştır. Aynı zamanda uygulama alanında yansıtmadan iki tane yansıtma yaptığı görülmektedir. Öğretmenin eleştirel alandaki cevaplarına bakıldığında yargıya varma kategorisinde yoğun kullandığı göze çarpmaktadır. Öğretmenin “Öğrencilerin genelinin başarılı olup olmadı̆̆ını, kavranıp kavranmadı̆̆ını gösteriyor. Öğrencilerin eksiklerini gösteriyor ve ek etkinlikler, uygulamalar yapmamı să̆llyor. Yaptı̆̆ım hataları bir daha yapmamam gerektiğini anlıyorum ve kendimi düzeltiyorum. Öğrencilerin kendilerini görmeleri açısından iyi oluyor..." şeklinde ifadeleri yargıya varmayı göstermektedir.

Öğretmenin akran değerlendirmesindeki ifadeleri analiz edildiğinde soruların çoğunluğuna eleştirel düzeyde yansıtmalarda bulunduğu ortaya çıkmıştır. Eleştirel alandaki yansıtıcı ifadeler yargıya varma ve öneri şeklindedir. Bunun yanı sıra teknik alanda yansıtma ifadelerde ortaya çıkmıştır. Yargıya varma kategorisindeki 
yansıtmaya örnek olarak "Bireylerin bilmek istediği noktalara değinilmiştir. Yapılan testlerle güzel bir ölçüm yapılmıştır....” şeklindeki yansıtma verilebilir.

Öğretmenin 6. haftada ölçme ve değerlendirme alanındaki yansıtıcı düşünme bulguları Tablo 6'da sunulmuştur.

Tablo 6.

Öğretmenin 6. Haftada Ölçme ve Dĕgerlendirme Alanında Yansıtıcı Düşünme Bulgularl

\begin{tabular}{|c|c|c|c|c|c|c|}
\hline & Sorular & Kategori & Kodlar & TAY & UAY & EAY \\
\hline \multirow{6}{*}{$\begin{array}{l}\text { Yansıtıcı } \\
\text { Günlük }\end{array}$} & 1 & $\begin{array}{l}\text { Gerekçesiz } \\
\text { Sonuç }\end{array}$ & $\begin{array}{c}\text { Genel anlamda etkili } \\
\text { olmuştur }\end{array}$ & $\mathrm{X}$ & & \\
\hline & 2 & Yapılandirma & ...yaptım & & & $\mathrm{x}$ \\
\hline & 3 & Öneri & ...y1 yapabilirdim & & & $\mathrm{x}$ \\
\hline & 4 & $\begin{array}{l}\text { Nedensellik } \\
\text { Oluşturma }\end{array}$ & $\begin{array}{c}\text {...nedeniyle } \\
\text { uygundu }\end{array}$ & & $\mathrm{x}$ & \\
\hline & 5 & Sorgulama & ...eksik yönümdü & & & $\mathrm{x}$ \\
\hline & 6 & $\begin{array}{l}\text { Gerekçesiz } \\
\text { Öneri }\end{array}$ & Kullanırdım & $\mathrm{X}$ & & \\
\hline Öz Değ. & 1 & $\begin{array}{l}\text { Uygulamada } \\
\text { Yansitma }\end{array}$ & $\begin{array}{c}\text {...uygulamaların } 1 \\
\text { yaptım }\end{array}$ & & $\mathrm{x}$ & \\
\hline \multirow{7}{*}{ Mülakat } & 18 & $\begin{array}{l}\text { Gerekçesiz } \\
\text { Öneri }\end{array}$ & ...yapmal1 & $\mathrm{x}$ & & \\
\hline & 19 & Sorgulama & ...y1 sorguluyorum & & & $\mathrm{x}$ \\
\hline & 20 & $\begin{array}{l}\text { Gerekçesiz } \\
\text { Sonuç }\end{array}$ & $\begin{array}{c}\text { Genellikle } \\
\text { ulaşabiliyorum }\end{array}$ & $\mathrm{x}$ & & \\
\hline & 21 & $\begin{array}{l}\text { Yargiya } \\
\text { Varma }\end{array}$ & ...y1 yapabiliyorum & & & $\mathrm{x}$ \\
\hline & 22 & Yapilandirma & $\begin{array}{c}\text {...gözden } \\
\text { geçiriyorum, daha } \\
\text { iyisini görüyorum. }\end{array}$ & & & $\mathrm{x}$ \\
\hline & 23 & Yapılandirma & $\begin{array}{l}\text {...gözden } \\
\text { geçiriyorum, daha } \\
\text { iyisini görüyorum. }\end{array}$ & & & $\mathrm{x}$ \\
\hline & 24 & $\begin{array}{l}\text { Gerekçesiz } \\
\text { Sonuç }\end{array}$ & Fayda sağlad 1 & $\mathrm{x}$ & & \\
\hline \multirow{6}{*}{$\begin{array}{c}\text { Akran } \\
\text { Değ. }\end{array}$} & 11 & $\begin{array}{l}\text { Gerekçesiz } \\
\text { Öneri }\end{array}$ & ...y1 yapabilirdi & $\mathrm{x}$ & & \\
\hline & 12 & $\begin{array}{l}\text { Gerekçesiz } \\
\text { Sonuç }\end{array}$ & ...ya ulaşabildi. & $\mathrm{x}$ & & \\
\hline & 13 & Öneri & $\begin{array}{c}\text {...nedeniyle o bunu } \\
\text { yapabilirdi. }\end{array}$ & & & $\mathrm{x}$ \\
\hline & 14 & $\begin{array}{l}\text { Yargiya } \\
\text { Varma }\end{array}$ & $\begin{array}{l}\text {...gözden geçirmiş, } \\
\text { daha iyisini } \\
\text { görmüştür }\end{array}$ & & & $\mathrm{x}$ \\
\hline & 15 & $\begin{array}{l}\text { Yargiya } \\
\text { Varma }\end{array}$ & O yapabilmiştir & & & $\mathrm{x}$ \\
\hline & 16 & Öneri & $\begin{array}{c}\mathrm{O}, \text { nedeniyle bunları } \\
\text { yapabilirdi }\end{array}$ & & & $\mathrm{x}$ \\
\hline
\end{tabular}


Ö1 kodlu YDOTÖ öğretmenin yansıtıcı günlüklerde yer alan ölçme ve değerlendirmeye yönelik sorulara vermiş olduğu cevaplar incelendiğinde öğretmenin üç adet eleştirel, iki adet teknik ve uygulama alanında bir tane yansıtma düzeyine yönelik ifadeler kullandığı görülmektedir. Ö1 kodlu öğretmenin ifadeleri incelendiğinde, eleştirel alanda sorgulama, yapılandırma ve öneriye yönelik olduğu ortaya çıkmıştır. Bu duruma Ö1 kodlu öğretmenin ölçme değerlendirmeye yönelik sorulan soruya vermiş olduğu "Soru-cevap tekniğinin kullanımını arttırdım çünkü diğer ölçme değerlendirme yöntemleri ögrrencinin sadece yazma becerilerine yönelikti." şeklindeki ifadesi yapılandırma kategorisine örnek olarak verilebilir. Ö1 kodlu öğretmenin ifadeleri incelendiğinde, teknik alanda gerekçesiz sonuca yönelik ifadeler olduğu ortaya çıkmıştır. Bu duruma " Genel anlamda etkili olmuştur..." şeklindeki söylemi örnek verilebilir.

Öz değerlendirme formunda ölçme ve değerlendirmeye yönelik sorulan soruda öğretmen uygulama alanda yansıtıcı ifadeler kullanmıştır. Bu ifade incelendiğinde öğretmenin içeriğe yönelik kullandığ 1 "Öğrencilerin kullanımlartyla değerlendirmeye çallşstım. Yönleri ve tarifleri anladıkların ve uygulamalarla gösterdiklerini...." şeklinde uygulamada yansıtmaya örnek teşkil etmektedir.

Ölçme ve değerlendirmeye yönelik sorulan mülakat sorularına öğretmen ağırlıklı olarak eleştirel alanda yansıtma alanına uygun ifadeler kullanmıştır. Aynı zamanda teknik alanda yansıtmadan üç tane yansıtma yaptı̆̆ 1 görülmektedir. Öğretmenin eleştirel alandaki cevaplarına bakıldığında yapılandırma kategorisinde yoğun kullandığı göze çarpmaktadır. Öğretmenin "Bazen kendi akranımızda biz de olmayan, eksik şeyleri görebiliyoruz. Noksanları gözlemlediğimizde bu yönde tavsiyelerde bulunabiliyoruz..." şeklinde ifadeleri yapılandırma yaptığını göstermektedir.

Öğretmenin akran değerlendirmesindeki ifadeleri analiz edildiğinde soruların çoğunluğuna eleştirel düzeyde yansıtmalarda bulunduğu ortaya çıkmıştır. Eleştirel alandaki yansıtıcı ifadeler yargıya varma ve öneri şeklindedir. Bunun yanı sıra teknik ve uygulama alanında yansıtma da ifadelerde ortaya çıkmıştır. Yargıya varma kategorisindeki yansitmaya örnek olarak "özgün konuşması ve üslubuyla, farkl fikirlerle verdiği tanımsal örneklerle yansıtıcı düşünmeyi etkin kılmışır." ş̧eklindeki yansitma verilebilir.

Öğretmenin 7. haftada ölçme ve değerlendirme alanındaki yansıtıcı düşünme bulguları Tablo 7'de sunulmuştur.

Tablo 7.

Öğretmenin 7. Haftada Ölçme ve Değerlendirme Alanında Yansıtıcı Düşünme Bulgularl

\begin{tabular}{|c|c|c|c|c|c|c|}
\hline & Sorular & Kategori & Kodlar & TAY & UAY & EAY \\
\hline \multirow{2}{*}{ 音 } & 1 & Yargiya Varma & $\begin{array}{c}\text { Etkili olduğunu } \\
\text { düşünüyorum }\end{array}$ & & & $\mathrm{x}$ \\
\hline & 2 & $\begin{array}{l}\text { Gerekçesi } \\
\text { Sonuç }\end{array}$ & Düşünüyorum & $\mathrm{x}$ & & \\
\hline
\end{tabular}




\begin{tabular}{|c|c|c|c|c|c|c|}
\hline \multirow[b]{5}{*}{ 01 } & 3 & $\begin{array}{l}\text { Gerekçesiz } \\
\text { Sonuç }\end{array}$ & Söyleyebilirim & $\mathrm{x}$ & & \\
\hline & 4 & $\begin{array}{l}\text { Nedensellik } \\
\text { Oluşturma }\end{array}$ & Nedeniyle etkili oldu & & $\mathrm{x}$ & \\
\hline & 5 & $\begin{array}{l}\text { Nedensellik } \\
\text { Oluşturma }\end{array}$ & Nedeniyle etkisiz oldu & & $\mathrm{x}$ & \\
\hline & 6 & Öneri & $\begin{array}{c}\text { Testler geliştirmek } \\
\text { isterdim }\end{array}$ & & & $\mathrm{x}$ \\
\hline & 1 & $\begin{array}{l}\text { İhtiyaç } \\
\text { Yansitma }\end{array}$ & $\begin{array}{c}\text { Öğrencilerin } \\
\text { ihtiyaçlarına göre } \\
\text { değildi }\end{array}$ & & $\mathrm{x}$ & \\
\hline \multirow{7}{*}{ 劳 } & 18 & Yargiya Varma & Bana katk1 sağladı & & & $\mathrm{x}$ \\
\hline & 19 & Yargiya Varma & $\begin{array}{c}\text { Amacıma ulaş九tı̆ımı } \\
\text { görüyorum }\end{array}$ & & & $\mathrm{x}$ \\
\hline & 20 & $\begin{array}{c}\text { Gerekçesiz } \\
\text { Sonuç }\end{array}$ & Bana gösterdi & $\mathrm{x}$ & & \\
\hline & 21 & Yargiya Varma & ...bana fayda sağlad 1 & & & $\mathrm{x}$ \\
\hline & 22 & $\begin{array}{c}\text { Basit } \\
\text { Tanımlama }\end{array}$ & Bana gösterdi & $\mathrm{x}$ & & \\
\hline & 23 & Yargiya Varma & Hata oranını azaltiyor & & & $\mathrm{x}$ \\
\hline & 24 & $\begin{array}{c}\text { Basit } \\
\text { Tanımlama }\end{array}$ & ... etkili oldu & $\mathrm{x}$ & & \\
\hline \multirow{6}{*}{$\frac{E}{\pi}$} & 11 & Yargiya Varma & $\begin{array}{l}\ldots \text { değerlendirme } \\
\text { yapılmıştır }\end{array}$ & & & $\mathrm{x}$ \\
\hline & 12 & Yargıya Varma & $\begin{array}{c}\text {...bilgiler } \\
\text { verilebilmiştir }\end{array}$ & & & $\mathrm{x}$ \\
\hline & 13 & $\begin{array}{l}\text { Gerekçesiz } \\
\text { Öneri }\end{array}$ & $\begin{array}{c}\text { Bilimsel araştırma } \\
\text { yöntemlerinden } \\
\text { yararlanırdım }\end{array}$ & $\mathrm{x}$ & & \\
\hline & 14 & $\begin{array}{c}\text { Teori- } \\
\text { Uygulama } \\
\text { Bağlantıs1 } \\
\end{array}$ & $\begin{array}{l}\text { Teorinin uygunluğunu } \\
\text { sağlamıştır }\end{array}$ & & $\mathrm{x}$ & \\
\hline & 15 & $\begin{array}{l}\text { Gerekçesiz } \\
\text { Sonuç }\end{array}$ & Evet kullanabilmiştir & $\mathrm{x}$ & & \\
\hline & 16 & Öneri & ...bilincinde olurdum & & & $\mathrm{x}$ \\
\hline
\end{tabular}

Ö1 kodlu YDOTÖ öğretmenin yansıtıcı günlüklerde yer alan ölçme ve değerlendirmeye yönelik sorulara vermiş olduğu cevaplar incelendiğinde öğretmenin ikişer adet eleştirel ve uygulama alanında bir tene de teknik alanda yansıtma düzeyine yönelik ifadeler kullandığı görülmektedir. Ö1 kodlu öğretmenin ifadeleri incelendiğinde, eleştirel alanda yargıya varma ve öneriye yönelik olduğu ortaya çımıştır. Bu duruma Ö1 kodlu öğretmenin ölçme değerlendirmeye yönelik sorulan soruya vermiş olduğu "Genel bir ders tekrarl olduğu için hangi ölçme yöntem ve tekniği kullanırsam kullanayım faydalı olacağını düşünüyorum ancak bu dersimde soru cevap, doğru-yanlış, kisa cevapl yazll yoklama ve çoktan seçmeli soru 
yöntemlerini kullandım ve etkili olduğunu düşünüyorum." ş̧eklindeki ifadesi yargıya varma kategorisine örnek olarak verilebilir. .. Ö1 kodlu öğretmenin ifadeleri incelendiğinde, uygulama alanında nedensellik oluşturmaya yönelik olduğu ortaya çıkmıştır. Bu duruma " konuların fazla olması ve soru sayısının bazen fazla olması ögrenciyi sıkmaktadır..." şeklindeki söylemi örnek verilebilir.

Öz değerlendirme formunda ölçme ve değerlendirmeye yönelik sorulan soruda öğretmen uygulama alanda yansıtıcı ifadeler kullanmıştır. Bu ifade incelendiğinde öğretmenin içeriğe yönelik kullandığ 1 “Öğrencilerin alıştırmaya verdikleri cevapların doğruluk oranına göre bir ölçme değerlendirme yapmaya çalıştım. Sistematik değildi." şeklinde cevabı ihtiyaç yansıtmaya örnek teşkil etmektedir.

Ölçme ve değerlendirmeye yönelik sorulan mülakat sorularına öğretmen ağırlıklı olarak eleştirel alanda yansıtma alanına uygun ifadeler kullanmıştır. Aynı zamanda teknik alanda yansıtmadan üç tane yansıtma yaptığı görülmektedir. Öğretmenin eleştirel alandaki cevaplarına bakıldığında yargıya varma kategorisinde kullandığı göze çarpmaktadır. Öğretmenin "Yansitıcı düşünme ve öz değerlendirme birbiriyle bağlantıll iki kavram. Öz değerlendirme yaparak kendimi her zaman daha iyisine zorluyorum. Mesleki açıdan gelişmem de fayda sağllyor." şeklinde ifadeleri yargıya vardığını göstermektedir.

Öğretmenin akran değerlendirmesindeki ifadeleri analiz edildiğinde soruların çoğunluğuna eleştirel düzeyde yansıtmalarda bulunduğu ortaya çıkmıştır. Eleştirel alandaki yansıtıcı ifadeler yargıya varma ve öneri şeklindedir. Bunun yanı sıra teknik ve uygulama alanında yansıtma da ifadelerde ortaya çıkmıştır. Öneri kategorisindeki yansıtmaya örnek olarak " $\ddot{z} z$ eleştiri faaliyetlerinde bulunarak değerlendirmelerden ders çıkardım yaptıklarımı değerlendirerek sorumluluğumun bilincinde olurdum." şeklindeki yansıtma verilebilir.

Öğretmenin 8. haftada ölçme ve değerlendirme alanındaki yansıtıcı düşünme bulguları Tablo 8'de sunulmuştur.

Tablo 8.

Öğretmenin 8. Haftada Ölçme ve Değerlendirme Alanında Yansitıcı Düşünme Bulgulart

\begin{tabular}{|c|c|c|c|c|c|c|}
\hline & $\begin{array}{c}\text { Sorula } \\
\mathbf{r}\end{array}$ & Kategori & Kodlar & $\begin{array}{c}\text { TA } \\
\mathbf{Y}\end{array}$ & $\begin{array}{c}\text { UA } \\
\mathbf{Y}\end{array}$ & $\begin{array}{c}\text { EA } \\
\mathbf{Y}\end{array}$ \\
\hline & 1 & $\begin{array}{c}\text { Basit } \\
\text { Tanımlama }\end{array}$ & $\begin{array}{c}\text { Genel anlamda etkili } \\
\text { olmuştur }\end{array}$ & $\mathrm{x}$ & & \\
\hline \multirow{2}{*}{$\begin{array}{c}\text { Yansıtıc } \\
\text { I } \\
\text { Günlük }\end{array}$} & 2 & $\begin{array}{c}\text { Nedensellik } \\
\text { Oluşturma }\end{array}$ & Çünkü...düşünüyorum & & $\mathrm{x}$ & \\
\hline & 3 & $\begin{array}{c}\text { Yeniden } \\
\text { Yapılandırm } \\
\text { a }\end{array}$ & ...yapabilirdim & & & $\mathrm{x}$ \\
\hline
\end{tabular}




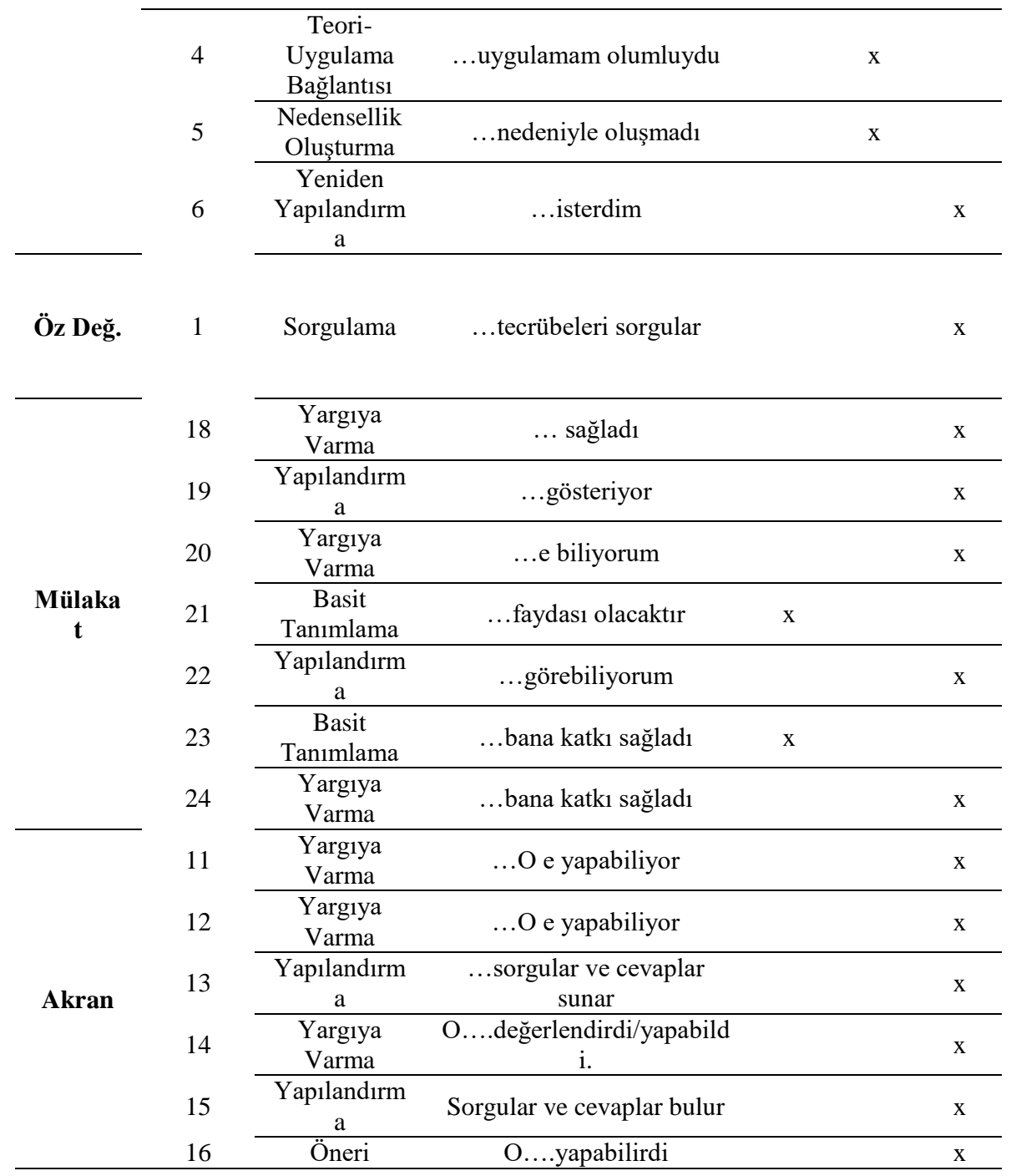

Ö1 kodlu YDOTÖ öğretmenin yansıtıcı günlüklerde yer alan ölçme ve değerlendirmeye yönelik sorulara vermiş olduğu cevaplar incelendiğinde öğretmenin ağıllıklı olarak uygulama alanda yansıtma düzeyine yönelik ifadeler kullandığı görülmektedir. Bunun yanı sıra teknik alanda ve eleştirel alanda yansıtmaya da birer cevap vermiştir. Ö1 kodlu öğretmenin ifadeleri incelendiğinde, ifadelerin büyük bir kısmının nedensellik oluşturmaya yönelik olduğu ortaya çıkmıştır. Bu duruma Ö1 kodlu öğretmenin ölçme değerlendirmeye yönelik sorulan soruya vermiş olduğu "Soru cevap tekniğinin kullanımını arttırdım çünkü emir kipinin en iyi konuşularak 
anlaşılacă̆ını düşünüyorum." şeklindeki ifadesi nedensellik oluşturma kategorisine örnek olarak verilebilir.

Öz değerlendirme formunda ölçme ve değerlendirmeye yönelik sorulan soruda öğretmen eleştirel alanda yansıtıcı ifadeler kullanmıştır. Bu ifade incelendiğinde öğretmenin içeriğe yönelik kullandığı “Öğrenci performanslarından bir ölçme işlemi yapmayı düşünmüşı̈̈m. Bu şekilde yol izledim. Belirli bir yöntem kullanmadım. Konuşmalarından gözlemlemeye çalıştım." şeklinde cevabı sorgulamaya örnek teşkil etmektedir.

Ölçme ve değerlendirmeye yönelik sorulan mülakat sorularına öğretmen ağılık olarak eleştirel alanda yansıtma alanına uygun ifadeler kullanmıştır. Aynı zamanda teknik alanda yansıtmadan da iki tane yansıtma yaptığı görülmektedir. Öğretmenin eleştirel alandaki cevaplarına bakıldığında yapılandırma ve yargıya varma kategorilerinde ifadeler kullandığı göze çarpmaktadır. Öğretmenin "Akran değerlendirmeyi genelde kendi ögrencilerim arasında kullanmaya çallşıyorum. Ya da kendi meslektaşlarımla da yapmaya çalışılyorum ... beni değerlendirmesini olumlu karşıllyorum." şeklinde ifadeleri yargıya vardığını göstermektedir.

Öğretmenin akran değerlendirmesindeki ifadeleri analiz edildiğinde soruların tamamına eleştirel düzeyde yansıtmalarda bulunduğu ortaya çıkmıştır. Eleştirel alandaki yansıtıcı ifadeler ağırlıklı olarak yargıya varma şeklindedir. Bunun yanı sıra yapılandırma ve öneri kategorilerine yönelik eleştirel yansıtıcı ifadelerde ortaya çıkmıştır. Öneri kategorisindeki yansıtmaya örnek olarak "Sunumda kullandı̆gım slayttın sonunda anketsel faaliyetlerde bulunarak grup tartışması yapardım. Sonra da yaptıklarımı değerlendirirdim." şeklindeki yansitma verilebilir.

\section{Tartışma, Sonuç ve Öneriler}

YDOTÖ öğretmenlerinin yaptığı yansıtıcı düşünme etkinlikleri öğretmenleri, kendi inançlarını, bilgi ve birikimlerini; eleştirmiş ve onlara kendilerini sorgulamaları konusunda cesaret vermiş̧ir. Öğretmenlerimiz ders planı yaparken de sınıfın seviye, sosyal- kültürel yapısını önemseyip dikkate almışlar, sınıfta öğrencilere kazandırmak istedikleri amaç ve kazanımlara uygun bir ders hazırlamaya çalışmışlardır.

Araştırmada, öğretmenler uygulamalar esnasında süreçleri değerlendirdikleri, bir sonraki dersin planlamasına yönelik kararlar aldıkları, hatalarını, eksikliklerini fark edip düzeltemeye çalıştıkları, kendilerini tarafsız bir şekilde eleştirme fırsatı buldukları sonucuna ulaşılmıştır.

Yabancı dil olarak Türkçe öğreten öğretmenlere yapılan bu yansıtıcı günlük uygulaması ile öğretmenlik becerilerinin arttığını, kendileri ile ilgili farkındalık oluşturmaya başladıkları, dersin başlangııından sonucuna kadar yaptıkları her şeyi 
sorgulama, yapılandırma, karşılaştırma ve değerlendirme firsatı buldukları sonucuna ulaşılmıştır.

Araştırmada yaptığımız mikro öğretim ile öğretmenlerin dersleri video ile kayıt altına alınmıştır. Bu videoların incelenmesi öğretmenlerin yansıtıcı düşünmesine katkı sağlamıştır. Öğretmenler sınıfta kendilerinin o anda göremedikleri hatalarını görmüş, sınıf içi düzendeki eksikliklerini fark etmişlerdir.

Yabancı dil olarak Türkçe öğreten öğretmenler üzerinde yaptığımız akran değerlendirmesi ile öğretmenler birbirlerine yapıcı eleştiriler getirmişlerdir. Yapılan eleştirilerde öğretmenler akranlarının ders sürecinde yaptıkları hataları söylemiş ve bunların çözümünde yapılması gerekenleri önermişlerdir. Öğretmenin öğretim sürecinin değerlendirme aşamasındaki gelişiminin ortaya konulması amaçlandığı bu çalışmada elde edilen sonuçlara yönelik aşağıdaki öneriler getirilmiştir.

- Yabancı dil olarak Türkçe öğreten öğretmenler, kendi derslerinin kayıt altına alındığı video kayıtlarını izlerken kullandıkları öğretim ilke ve yöntemlerini, hedefiçeriğini, öğretim materyaller ve tasarımlarını, ölçme ve değerlendirme yöntemlerini, görmektedirler. Bu videolar yeni başlayan öğretmenlerimizin gelişiminde de büyük katkı sağlayacağı ortadadır. Bu yüzden mikro öğretim uygulamalarına sıklıkla yer verilmelidir.

- Yansitıcı düşünme becerilerinin geliştirilmesinde birden fazla aracın kullanılması gerekmektedir. Yansitıc1 günlük, öz değerlendirme, akran değerlendirme, ders planı, mikro öğretim, video kayıtları, mülakat ve geribildirimler burada etki gösterebilir. Düşünme alışkanlığı kazandırılması açısından bu uygulamaların dersin en başından başlanmalı ve alışkanlık haline getirilmelidir.

- Yabancı dil olarak Türkçe öğreten öğretmenlerinin; düşüncelerinin, tutumlarının, hal ve hareketlerinin gelişmesini görmek için yabancı dil olarak Türkçe öğreten sertifika programlarına, yansitıcı günlük, öz değerlendirme, akran değerlendirme, ders planı, mikro öğretim, video kayıtları, mülakat, SWOT analizi, öğretmen öğrenme soruları eklenmelidir.

\section{Kaynakça}

Alp, S. \& Taşkın, Ş.Ç. (2007). Eğitimde yansıtıcı düşüncenin önemi ve yansıtıcı düşünceyi geliştirme. Milli Eğitim Dergisi, 178, 311-320.

Bilgin, N. (2014). Sosyal bilimlerde içerik analizi: Teknikler ve örnekler çalışmalar. Ankara: Siyasal.

Dervent, F. (2012). Yansitıcı düşünmenin beden ĕgitimi öğretmen adaylarının mesleki uygulamalarına etkisi (Yayınlanmamış doktora tezi). Marmara Üniversitesi, İstanbul.

Dolapçıŏlu, S.D. (2007). Sınıf öğretmenlerinin yansıtıcı düşünme düzeylerinin değerlendirilmesi (Yayınlanmamış yüksek lisans tezi). Mustafa Kemal Üniversitesi, Hatay.

Gökçe, O. (2006). İçerik analizi kuramsal ve pratik bilgiler. Ankara: Siyasal. 
Johnson, B. \& Christensen, L. (2014). Eğitim araştırmaları (Çev. Ed. S.B. Demir), Ankara: Eğiten Kitap.

Merriam, S.B. (2013). Nitel araştırma-desen ve uygulama için bir rehber-Oualitative research a guide to desing and inplementation. (Çev. Ed. S. Turan,). Ankara: Nobel.

Miles, M.B. \& Huberman, A.M. (2015). Nitel veri analizi. (Çev. S. Akbaba Altun ve A. Ersoy) Ankara: Pegem Akademi Yayınları.

Milli Eğitim Bakanlığı (2010). Türkçenin yabancı dil olarak ögretimi ve bu alan için öğretmen yetiştirmenin önemi ve gereği. Marmaris: Yabanc1 Dil Olarak Türkçe Öğretimi ve Öğretmenliği Çalıştayı Kitabı.

Rodgers, C. (2002). Definingreflection: anotherlook at johndewey ve reflectivethinking. Teacher College Record. 104(4), 842-886.

Taggart, G.L. \& Wilson, A.P. (2005). Promoting reflective thinking in teachers: 50 action strategies. California: Corwin Press.

Yeşilbursa, A. (2011). Reflection at theinterface of theoryandpractice: An analysis of preservice English languageteachers' writtenreflections. AustralianJournal of TeacherEducation, 36, 104-116.

YÖK, (2007). www.yok.gov.tr/documents/10279/49665/aciklama_programlar/aa7bd0919328-4df7-aafa 2b99edb6872f adresinden 17.02.2016 tarihinde edinilmiştir.

\section{Extended Abstract}

In the process of teaching Turkish as a foreign language, it is thought that having suffient knowledge of specific structures of Turkish language is very important for Turkish teachers. It can be stated that Turkish or Turkish language and literature education department graduates are more competent than graduates of foreign language teaching department of education faculties in teaching Turkish to foreigners. However, there are some shortcomings in the context of these graduates' teaching Turkish to foreigners because they are trained to teach Turkish to whose native language is Turkish. Therefore, it is considered that it would be useful to train teachers through separate departments in order to provide specialization in teaching Turkish to foreigners.

This research, designed to teach the reflective thinking to a teacher who teaches Turkish as a foreign language, to help his/her professional development and to show the development of the reflective thinking in the evaluation phase of the teaching, was designed as an action research because of the nature of the situation examined. Action research is described in many different forms in the literature. Action research is a systematic research process in which teacher is also researchers in order to learn how to learn better, how to teach and how their schools work (Mills, 2003).

In qualitative research, the researcher firstly decides what to do and who will be investigated in his/her research. The universe and events are determined by proposed or developed research. Generally, the criteria or qualifications of the individuals to be 
included in the experimental group are determined. These criteria are used to distinguish who is to be included in the study and who is not to be included. After these criteria are determined, the researcher starts to create experimental group (Johnson and Christensen, 2014, p.235).

In current research, criteria will be developed by the researcher. The criteria in this study are that the teacher works in TÖMER and teaches Turkish as a foreign language at A level. In this context, the study group of the research is formed by a teacher who teaches Turkish to foreigners in İstanbul Aydın University TÖMER. The name of the teachers will not be stated who are participated in the research and the teacher ise numbered as Ö1. Another important criterion is that the teachers are volunteers to participate in the research. The teacher's willingness to contribute to the research was an important criterion for their involvement in the study group. In summary, the sampling method used in the research, based on the above mentioned theoretical information, is a purposive sampling of non-selective sampling methods. Critical sampling method was used in the research.

Data collection tools' validity is provided through 2 expert academics' opinions, who study in the field of reflective thinking. The questions in the data collection tools were also confirmed by the experts' opinions that these questions are related with reflective thinking. In other words, all questions are suitable to measure intended gains. Regardless of the research group, questions were asked to ten teachers to verify the understanding and clearness of the questions and to provide reliability. Questions were rewritten which were difficult to understand,.

In the analysis of the data obtained from the measurement tools, the content analysis method was used. As a matter of fact, content analysis is an analysis method that historians and litterateurs use for document analysis (Merriam, 2013, p.144). In this context, the documents for this research are teachers' responses to the questions of measurement tools. In content analysis, homogeneous data are categorized as concepts and themes. Some processes are carried out in content analysis (Y1ldırım and Şimşek, 2013, p.259). The main processes of content analysis are as follows:

i) Diagnosing the problem: Determining the research question / purpose and formulating the assumptions,

ii) Creating a category system: Identifying categories and determining encoding rules,

iii) Identifying measurement units: Defining the units of coding and analysis and determining the sampling method (Gökçe, 2006, p.51).

Reflective thinking activities that are held by TTAFL (Teaching Turkish as a foreign language) teachers, made them to criticize their own beliefs and knowledge; and encouraged them to question themselves. When our teachers prepared the course plan, they took into consideration the level and social-cultural structure of the students 
as well as they tried to prepare a lesson in the classroom in accordance with the aims and achievements they wanted to students gain.

In the research, it was concluded that the teacher evaluated the processes during the practices, made decisions about planning of the next lesson, realized their mistakes and tried to correct these mistakes, and found an opportunity to criticize themselves objectively. It has been concluded that teachers who teach Turkish as a foreign language have increased their teaching skills, they have started to raise awareness about themselves and they had the opportunity to question, construct, compare and evaluate everything they did from the beginning to the end of the lesson through reflective diary practice. The micro teaching and the teachers' lessons were recorded through video. Examination of these videos contributed to the reflective thinking of teachers. Teachers have noticed the errors that they didn't notice in the classroom at that time and they have noticed their shortcomings in the classroom. Teachers criticized constructively each other with the peer assessment which was administered on teachers who teach Turkish as foreign language. The teachers have told their peers about the mistakes they made during the teaching process and made suggestions about what should be done for solution of those mistakes in peer assessment. The following recommendations were made for the results obtained in this study, which aims to reveal the development of the teacher's teaching process in the evaluation phase. 